RERLATIE MIE MALLED

Campinas-SP, v.38, n.2, pp. 885-918, jul./dez. 2018

\title{
HOMOEROTISMO E SUBALTERNIDADE EM PAULICEA DESVAIRADA ${ }^{1}$
}

\author{
Jorge Vergara ${ }^{2}$
}

\begin{abstract}
Resumo: Proponho cinco tropos para relacionar as manifestações de homoerotismo com as de subalternidade em Paulicea desvairada (1922), de Mário de Andrade: mulheres emendadas, impossíveis, desamparadas; passeios noturnos ou mirar no perigo; congresso de marginais; o medo incita o desejo; e normalidade cativa. Além da estilização poética, a homofobia internalizada de Mario de Andrade permite supor o motivo pelo qual não há clara expressão das ideias homoeróticas e explica em parte a rejeição do imaginário obsceno. A estilização em Paulicea é testemunha de como a sociedade condenou práticas e pessoas à ignomínia e ao silêncio. As insinuações poéticas instigam questionamentos, pensamento e imaginação. Com conceitos da teoria queer, da análise do discurso, da história, da historiografia da homossexualidade no Brasil, através de pesquisa em textos, músicas e a medicina da época mais a correspondência de Mário de Andrade, exploro a temática homoerótica e política que jaz na poesia do musicólogo.
\end{abstract}

Palavras-chave: Mário de Andrade; homofobia; subalternidade.

De que maneira se postula a homossexualidade e a bissexualidade de Mário de Andrade? Moacir Werneck de Castro (1989, pp. 92-93) e Rachel de Queiroz (1998, pp. 112 e 115) alegam perceber, fruto de convivência, o elemento homossexual no comportamento de Mário. Castro chega a essa conclusão após pensar no assunto, e Queiroz o retrata como autoevidente. A respeito da homossexualidade na literatura de Mário, João Luiz Lafetá (1986, p. 117) escreve sobre o homoerotismo reprimido na obra dele, Jaime Ginzburg (1993, p. 107) encontra a "afetividade homoerótica [...] nunca

1 Este texto faz parte de uma tese de doutorado, realizada graças a uma bolsa de estudos concedida pela Capes.

2 Doutor pelo Programa de Pós-Graduação em Música (PPGM) da Universidade Federal do Estado do Rio de Janeiro (UNIRIO): <jorgevergara1977@gmail.com>. 
inteiramente assumida pelo protagonista” e Ivone Rabello (1999, pp. 214 e 216) observa relação autobiográfica entre Juca (personagem em Contos novos) e Mário de Andrade: "Esse não é apenas o nome de Frederico; é também o nome do desejo que teima em existir, porque não realizado". Em conferência na Festa Literária Internacional de Paraty - FLIP, Eliane Robert Moraes (2015) argumenta que o erotismo e o homoerotismo poético de Mário é alusivo e, por isso, tão mais intenso. João Silvério Trevisan (2002, pp. 256-258) reprocha o ocultamento de referências à homossexualidade de Mário e ao homoerotismo dos seus textos pela academia e pela família do escritor. Na biografia de Mário de Andrade, Eduardo Jardim (2015, p. 135) o qualifica de homossexual sem justificar essa conclusão em detalhe. Não existe argumento ou conjunto de argumentos para definir o assunto.

Os casos de amor de Mário por mulheres são conhecidos, embora não exista discussão sobre casamento ou sexualidade (LOPEZ, 2011; JARDIM, 2015). Na correspondência considerada, Mário de Andrade nunca aceita a categoria de homossexual para si mesmo. Seja na carta a Manuel Bandeira de 7 de abril de 1928, lacrada até julho de 2015, ou na carta a Sergio Milliet de 30 de maio de $1923,{ }^{3}$ Mário reconhece sua reputação de homossexual ou pederasta. Sem negar rótulos, ele recusa qualquer confissão. Na carta a Milliet, Mário explica com orgulho que a pederastia o liga à genialidade artística, já que nomes reconhecidos por serem pederastas são considerados grandes artistas (ANDRADE, 1971, p. 289). Naquela carta que Bandeira chamou de "perigosa", 4 Mário alega que discutir a veracidade ou falsidade da percepção social é ineficiente, que se acostumou ao enquadramento social e, ao se explicar sem ser específico, imputa ao leitor a responsabilidade da interpretação:

Mas em que podia ajuntar em grandeza ou milhoria ${ }^{5}$ pra nós ambos, pra você, ou pra mim, comentarmos e eu elucidar você sobre a minha tão falada (pelos outros) homosexualidade? Em nada [...]. (ANDRADE, 1928, p. 3)

Mas si agora toco neste assunto em que me porto com absoluta e elegante discreção social, tão absoluta que sou incapaz de convidar um companheiro daqui, a sair sozinho comigo na rua (veja como eu tenho a minha vida mais regulada que maquina de precisão) e si saio com alguem é porquê esse alguem me convida, si toco no assunto é porquê se poderia tirar dele um argumento pra explicar minhas amizades platonicas, só minhas. Ah, Manú, disso só eu

\footnotetext{
3 A primeira encontra-se na Casa de Rui Barbosa (RJ), a segunda no Fundo Paulo Duarte (Unicamp).

4 Carta de 5 de maio de 1928 (ANDRADE; BANDEIRA, 2000, p. 387).

5 Optamos por manter a ortografia original em todas as citações de textos antigos.
} 
mesmo posso falar, e me deixe que ao menos pra você, com quem apesar das delicadezas da nossa amizade, sou duma sinceridade absoluta, me deixe afirmar que não tenho nenhum sequestro não. Os sequestros num caso como êste onde o físico que é burro e nunca se esconde entra em linha de conta como argumento decisivo, os sequestros são impossíveis. Eis aí uns pensamentos jogados no papel sem conclusão nem sequencia. Faça deles o que quiser. (ANDRADE, 1928, p. 4)

Práticas sexuais não são determinadas pela biologia de maneira absoluta. A homossexualidadeganha relevância em função da contingência social. Na teoria queer, conceitos de homo e heterossexualidade não são reais, mas "tecnologias sociopolíticas complexas", ${ }^{6}$ categorias para narrar situações específicas: as situações temporais em que elas ocorrem. Relaciono a tese segundo a qual os lugares de encontro entre homens permitiam a discriminação e exclusão feminina com a homossexualidade dissimulada. Do mesmo modo, a homossexualidade será ligada a pessoas e práticas subalternas, pois esses grupos se conectam em Paulicea desvairada.

O texto (e não só o poético) nunca oferece significados verificáveis, estáveis ou verdadeiros. O poeta elaborou e tergiversou nele, com artifícios que lhe interrompem o sentido. No "Prefácio interessantíssimo" explicam-se as condições da criação, pois o artista extrai seus temas "do mundo objetivo", mas ele necessita e descobre "exageros, sem exatidão aparente", para assim conduzir o leitor à "idealização livre, musical”, que "ultrapassa a defeituosa percepção dos sentidos" (ANDRADE, 1922, p. 19). O musicólogo associa a música à liberdade, nunca definida, e o caráter de manifesto vanguardista antecipa a imagem do poeta que critica as autoridades e se identifica com os subalternos: "O impulso lírico clama dentro de nós como turba enfuriada [...] A turba é confusão aparente. Quem souber afastar-se idealmente dela, verá o imponente desenvolver-se dessa alma coletiva, falando a retórica exata das reivindicações" (pp. 21-22).

O escritor reivindica a liberdade, e a frase "Toda canção de liberdade vem do cárcere" encerra o prefácio e teria a capacidade de suplantá-lo, caso fosse compreendida (ANDRADE, 1922, p. 39). Essa conclusão dá a entender que, sem discernir as relações de poder, a interpretação é ineficiente. É necessário explicar a manifestação do aspecto homoerótico dos textos. No que segue, utilizo a história, os estudos culturais e a

6 O queer, segundo Beatriz Preciado (2014; 2011, p. 16), que recupera Butler e Foucault. 
teoria queer para propor cinco tropos literários de modo a explicar essa manifestação e mostrar como Mário de Andrade expõe figuras socialmente marginalizadas em Paulicea desvairada.

\section{MULHERES EMENDADAS, IMPOSSÍVEIS, DESAMPARADAS}

A relação entre homoerotismo e exclusão feminina não é óbvia, pois o lugar público frequentado por homens não se relaciona automaticamente com práticas homossexuais ocultas. As mulheres não têm a mesma condição que os homens, e os espaços de poder e os espaços públicos são habitados por indivíduos que se associam para ter convivência entre si. As ideias que estigmatizam efeminados ou sodomitas, se não são semelhantes àquelas que depreciam a mulher, estão relacionadas a elas. ${ }^{7}$

Em O Aleijadinho e Alvarez de Azevedo, Mário de Andrade (1935, p. 8o) marca o desprezo de Azevedo por conversar com mulheres: ele "femininamente presta mais atenção a setins e escumilhas, que a corpos gostosos da gente apertar na valsa”. A mente feminina foi desprezada e seus corpos interessam, mas ele não aceita a leitura que percebe o uso da roupa em primeiro plano. Mário compara os elementos psicológicos "pouco masculinos" na expressão de sentimentos com os de outros poetas ("O poeta descora, desmaia, súa, e sente o peito 'langue" - ANDRADE, 1935, p. 91), e critica em Azevedo a educação "excessivamente entre sáias, que já é prejudicial pro desenvolvimento masculino dos rapazes" (p. 108). Para ele o "medo do amor inventa a idéia de possuir a bela adormecida" (p. 129). Mário escreve "medo do amor" para referir-se à prática sexual. Alusões explícitas ao sexual são raras: "amor" limpa e suaviza o texto sobre sexualidade. "Femininamente" serve para criticar a preocupação excessiva com roupas, mas em argumentação feminista ele escreve que o medo do amor é fruto da associação da sexualidade ao amor materno: "Na descrição de amores sexuais, Alvarez de Azevedo ainda encontra repetidamente imagens da maternidade" (p. 115). Mário questiona a excessiva idealização da mulher-mãe e denuncia a incapacidade de Azevedo em dissociar, da mulher, a maternidade, tema que levou este à repulsa imatura do desejo sexual.

7 No final do século dezenove e início do vinte, a submissão e a inferioridade femininas eram as constantes para pensar a relação entre os sexos no senso comum e nas teorias científicas (RAGO, 1991, pp. 78-79 e 141). 
A convivência com mulheres exporia a fragilidade do masculino: a ideia de que rapazes não devam conviver em excesso com mulheres, pois isso limitaria sua transformação em homens, persiste nos textos de medicina da época (MARAÑÓN, 1938, pp. 178, 276; RIBEIRO, 1938, p. 36): a partir de certo ponto, o jovem aprendiz da masculinidade poderia resistir aos desvios do feminino, mas a convivência em excesso não permitiria a construção da masculinidade forte e viril. A linha entre o certo e o incerto não é delimitada nem nos textos médicos nem nas considerações literárias analisadas, ela é o ponto cego desses discursos. A fragilidade do masculino possui outro registro: o medo da prostituição masculina e do homossexualismo que surge na ausência de mulheres e prostitutas. No livro Homosexualismo: a libertinagem no Rio de Janeiro, Pires de Almeida (1843-1913) ${ }^{8}$ argumenta que no século dezenove o governo resolveu importar prostitutas para acabar com a "prostituição masculina" (ALMEIDA, 1906, pp. 50, 52, 76), e na Guerra do Paraguai os homens que não encontravam fêmeas faziam sexo com homens (p. 162).

Aproximadamente quinze anos antes da publicação de Paulicea, Manuel Pedro dos Santos (cujo pseudônimo era Bahiano) gravou para a Casa Edison a cançoneta "O Francesco" (BAHIANO, 1907-1912). A letra supõe a associação entre "Francesco", "fresco" e "largo do Rocio". Explica-se através da narrativa da época:

\footnotetext{
Há uns certos "meninos" que se dão ao luxo de ir tomar fresco nos bancos do jardim do largo do Rocio. Mas não tomam só fresco. Vão mais longe. Costumam juntar-se a uns senhores e... muito agarradinhos, muito agarradinhos... com tregeitos de viuvinha ainda donzella, lá vão com elles para... (é facil de calcular para onde). E as familias que ali vão passeiar, e, principalmente, as moças casadeiras, estão desgostosas com a preferencia dada pelos cavalheiros a esses "mocinhos" indecentes. Mas não têm razão; porque, em verdade, fresco, bom fresco, só no largo do Rocio. É tradicional. (ANÔNIMO, 1912, p. 3)
}

Na canção há referências ao sexo anal eà prostituição noturna no Largo do Rocio no Rio de Janeiro. O texto em primeira pessoa e a interpretação da música com a ênfase e o retardo em "tremeliques", a hesitação e oscilação melódica antes de "Gregório", e as interjeições caracterizam o prostituto de forma engraçada:

8 Estudou direito e formou-se em medicina. Arquivista da Câmara Municipal e adjunto da Inspetoria Geral de Higiene do Rio de Janeiro, ele escreveu sobre educação, homossexualidade, literatura e teatro. 
Aqui estou eu que sou faceiro e bem macio,

Bem vestidinho ando sempre por detrás,

Sou morador aqui no Largo do Rocio,

Meus bons senhores, aqui estou pra tudo o mais.

Ai que frescuras, que roxuras ${ }^{9}$ já se vê, Sou bonitinho, faceirinho como o quê!

Lá no Rocio em tom macio sei falar,

Depois das onze ganho o meu bronze até fartar.

Bonitinho bem vestido em boa roda,

Flor no peito, bengalinha assim na mão,

Chapéu de palha, paletó curtinho à moda,

Faço nos homens tremeliques e sensação!

Com pó de arroz aqui na face sou finório,

Um cortinado tenho até no meu chatô,

Onde recebo muitas vezes o... Gregório,

Amigo meu que lá já foi e que gostou!

Depois do que, ali no Largo é um sucesso,

Eu só ouço: "bonitinho, venha cá",

Não levo a chincha ${ }^{10}$ porque logo cobre preço,

Pois sem arames $^{11} \mathrm{o}$ tubarão não entrará.

É que o famoso peixe-espada é arriscado,

E por isso eu não vou no arrastão,

Tenho medo de ficar todo engasgado,

E me estragarem a panela do feijão, ai ai!

(BAHIANO, 1907-1912, [s.p.])

Termos e expressões hoje dificilmente reconhecíveis da cançoneta "O Francesco" elucidam-se em diferentes números da revista O Rio Nú, em que se descrevem o Largo do Rocio e a prostituição masculina em termos quais: "bronze" (ANÔNIMO, 1898, p. 1), "tubarão" (ANÔNIMO, 1899, p. 2) e "depois das onze" (ANÔNIMO, 1900a, p. 3). "Bronze" alude à relação entre as estátuas e os frequentadores do lugar. "Eu sou de bronze" é referência aos que procuram rapazes ou à pertença destes ao grupo de frescos ou "doentes" ativos; ${ }^{12}$ mas na cançoneta pode significar o lucro

\footnotetext{
9 Tesão ou desejo sexual, também grafado "rochuras".

10 "Chamar na chincha" refere-se a resolver algo de forma definitiva.

11 "Sem arames": sem cobrar dinheiro.

12 "De noite fomos passear/ Faça calor, fresco ou frio/ Um sugeitinho encontrar.../ Isto lá depois das onze/ Todo cheio de massada.../ O tal sujeito é de bronze./ E quer conversa fiada!" (ANÔNIMO, 1899, p. 2). "Gregorio" que "costuma passeiar por aquelle largo à procura de meninos" é "famigerado doente", associado ao ativo (agente da penetração durante o ato sexual) que "vai atráz de ti", pois "não gosta de andar na frente" (ANÔNIMO, 1905, p. 2).
} 
monetário ou a obtenção do prazer físico. “Tubarão” refere-se àquele que procura "gente fresca".

Na seção "Concurso de resposta", propõe-se a escolha entre o sistema "moderno" e o "antigo" (sexo anal e vaginal, respectivamente). Os leitores inventam versos para o sexo anal: "Pois além de sujar o grão dedo/ Inda esfolla-se o dito Papai"; registram o nome que é código para o "ativo": "Tem por certo mais perigo,/ Mas eu cá não sou Gregório”; e aparece a frase da cançoneta: "Cá na minha opinião/ Gosto mais é pelo antigo,/ Pois, não sou lá muito amigo/ Da panella do feijão!" (ANÔNIMO, 190ob, p. 6). Existe congruência entre o uso dos termos na cançoneta e nos artigos de $O$ Rio Nú. Os conjuntos sugerem a existência de vocabulário comum entre as pessoas que conheciam o ambiente homoerótico. A leitura em paralelo da cançoneta e dos textos da revista reforça os sentidos referidos na música: as relações entre o másculo e o efeminado, quem paga e quem oferece serviço sexual, o ativo e o passivo, o maduro e o jovem, e principalmente deixa ver o segredo público ${ }^{13}$ das práticas sexuais entre homens.

O conceito que descreve essa situação é homossociabilidade (ROUSSEAU, 1999; SEDGWICK, 1998): os homens buscam seus iguais (sempre homens), relacionam-se afetivamente ou não, trocam ou negociam produtos, e, nessas práticas, as mulheres são moeda de troca. Algumas delas são esposas, mulheres legitimadas socialmente, podem ser exibidas em público. As prostitutas são mulheres com as quais não se estabelece aquele tipo de relacionamento, e que, por isso, sofrem outro tipo de exibição. O grau e a maneira da exclusão feminina dependem do lugar social. Dessa forma, a ideia de que há lugares que congregam homens e dos quais não participam as mulheres, ea ideia de que há lugares frequentados por homens queusam os corpos femininos relacionam-senão só pela exclusão e discriminação feminina nos ambientes onde os homens convivem como iguais, mas também pela possibilidade do homoerotismo surgir de maneira velada. Sem utilizar o termo homossociabilidade, o historiador Ronaldo Vainfas (2010) e o sociólogo Carlos Figari (2007) argumentam de forma similar, o primeiro em texto sobre a sexualidade no Brasil e o segundo, em análise sobre o homoerotismo no Rio de Janeiro.

13 Sedgwick (1998, p. 15, tradução minha) não usa a expressão, mas a ideia se deduz: “o fato de o silêncio ser tão intencionado e transformativo como o discurso, nas relações em torno do armário, depende de que a ignorância seja tão poderosa e múltipla como o conhecimento" ["el hecho de que el silencio sea tan intencionado y transformativo como el discurso, en las relaciones en torno del armario, depende de que la ignorancia sea tan poderosa y múltiple como el conocimiento"]. 
No poema "Tristura” de Paulicea (ANDRADE, 1922, pp. 71-72), a menção do famoso bordel Armenonville ${ }^{14}$ surge entre enumerações que aludem à castração e à solidão: 15 os desencontros e reuniões ("Nunca nos encontrámos.../ Mas há rendez-vous na meia-noite do Armenonville [...]"); a alegria aparente ("E dizem que os polichinelos são alegres!"); o amor oculto ou estranho ("Paulicea, minha noiva... Ha matrimónios assim.../ Ninguem os assistirá nos jamais!”); a solidão, filha do casamento ("E tivemos uma filha, uma só.../ [...] Chamei-a Solitude das Plebes"); a abjeção própria ("Imundo meu coração [...]"; "Minha alma corcunda"); e a obrigação da identidade única ou a proibição do desejo ("As permanéncias de ser um na febre!"). O verso final condensa o tema da castração, pois amizade, alegria e prazer são os "Pobres cabelos cortados da nossa monja". Os possessivos indicam que a monja representa São Paulo.

A prostituição feminina torna-se explícita no poema "Tu":

\author{
Mulher mais longa \\ que os pasmos alucinados \\ das tôrres de São Bento! \\ Mulher feita de asfalto e de lamas de várzea, \\ toda insultos nos olhos, \\ toda convites nessa boca louca de rubores! \\ Costureirinha de São Paulo, \\ ítalo-franco-luso-brasílico-saxónica, \\ gosto de teus ardores crepusculares, \\ crepusculares e por isso mais ardentes, \\ bandeirantemente! \\ Lady Macbeth feita de névoa fina, \\ pura neblina da manhã! \\ Mulher que és minha madrasta e minha irmã! \\ Trituração ascencional dos meus sentidos! [...] \\ Gosto dos teus desejos de crime turco \\ e das tuas ambições retorcidas como roubos! \\ Amo-te de pesadelos taciturnos, [...] \\ (ANDRADE, 1922, pp. 101-102).
}

A ousadia da prostituta é descrita com admiração: "ambições retorcidas como roubos", "toda insultos nos olhos", "teus desejos de crime

14 Ver Manfio e Duarte (1987, p. 591; 1975, pp. 122-125).

15 Lafetá (1986, pp. 41 e 117, respectivamente) cita a castração e a solidão na análise de "A costela do Grão Cão", e neste caso "a castração limita com o tema da homossexualidade, e [...] várias das imagens apontam este núcleo problemático”. 
turco". Palavras "alucinação", "ambições", "pesadelos”, "sonho medonho” e similares distinguem as construções da mente. $\mathrm{O}$ poema inclui a imaginação e alude a fragmentos da realidade que induziram desconforto e fascínio; esse deslumbramento reforça a percepção positiva, segundo a qual a prostituição teria permitido a reunião de paulistas de distintos grupos sociais (RAGO, 2005, p. 94; 1991, pp. 93 e 99). O poeta se exibe ao dizer que gosta dos mesmos desejos e ambições da prostituta-costureirinha. ${ }^{16} \mathrm{O}$ uso de imagens da família não facilita a compreensão, pois, se a ideia de ser filho ou irmão da prostituta provavelmente seria chocante à recepção da época, a imagem da família, por outro lado, pode ser interpretada como abrandamento das figuras ligadas ao desregramento sexual: "Mulher que és minha madrastra e minha irmã!".

O título e os epítetos advertem para o jogo poético em que o leitor é exposto à intimidade, pois o poeta encena o discurso imaginário frente à prostituta ("Tu Mulher mais longa [...]"). Ela recebe atributos masculinos através de expressões - "mais longa" que os "pasmos alucinados / das tôrres de São Bento!” -, quando seu desejo sexual é adjetivado com o advérbio "bandeirantemente". Também quando o poeta sugere ser seu desejo manipulado e desfeito pela mulher e não por ele mesmo, na frase em que o órgão sexual feminino substitui seu corpo: “Tu [...] Trituração ascensional dos meus sentidos!”. A potência do corpo feminino obtém seu sentido mais estranho com "trituração": o termo ocupa o lugar da elevação masculina do poeta. Se fosse possível normalizar, a frase seria "Prazer ascencional dos meus sentidos!”, mas a palavra que Mário usa explica o que a vagina faz com o pênis durante o ato sexual: comprime ou amassa. A prostituta conduz o ato.

No oratório "As Enfibraturas do Ipiranga” (ANDRADE, 1922, p. 120), o poeta encarna o papel feminino ("Minha Loucura - Soprano ligeiro Solista" - p. 122), participante na rebelião social (cifrada na expressão "Na Aurora do Novo Dia” - p. 130), que incomoda as figuras masculinas do poder econômico, a horda que o passado hipnotizou ("As Senectudes Tremulinas - milionários e burguezes” - p. 120), a insultar essa mulher: "Quem é essa mulher!/ É louca, mas louca/ pois anda no chão!”. O escritor escolheu a figura louca e feminina para tomar partido e ofender consensos sociais: em Paulicea, o feminino é subalterno do masculino e a loucura, da razão; a

16 Pires de Almeida (1906, p. 53) nomeia as profissões relacionadas com a prostituição: operárias, floristas, modistas, costureiras. Em O Rio Nú de 26 de março de 1904 a expressão "trabalho de agulha" é alusão à prostituição feminina (ANÔNIMO, 1904, p. 2). 
oposição ao imaginário autoritário provém da empatia pelas personagens, não consideradas nos esquemas oficiais por volta de 1920. O poeta se identifica com os subalternos. Na alucinação poética, os agitadores são surdos e os passadistas, cegos. Falta aos primeiros a sutileza (na imagem da nuance musical ou poética inaudível) e, aos segundos, a identificação com os outros e a percepção do real. O poeta escolhe os perdedores e antevê a reação à utopia: "AS JUVENILIDADES AURIVERDES E MINHA LOUCURA adormecem eternamente surdos; enquanto das janelas dos palácios, teatros, tipografias, hoteis - escancaradas, mas cegas - cresce uma enorme vaia de assovios, zurros, patadas" (ANDRADE, 1922, p. 140).

Tomar partido é aquilo que Mário chamou de arte interessada. A criação competente depende da interpretação do real, mesmo que essa criação fabrique aspectos fantásticos ou irreais.

\section{PASSEIOS NOTURNOS OU MIRAR NO PERIGO}

A associação alude a passeios noturnos, à natureza e induz o medo pela referência a situações ameaçadoras, mas o perigo e o crime não ganham detalhes. No ambiente da prostituição pode-se deduzir o flerte de homens que fazem sexo com homens: "As turmas ou clubes de homossexuais sempre constituíram uma necessidade, seja simplesmente para encontrar companheiros (de cama ou afeto), forjar amigos, assistir-se mutuamente e sobretudo experimentar o 'reconhecimento' entre 'iguais"' (FIGARI, 2007, p. 301). Em "Nocturno", a seguir, esses sentidos surgem pela justaposição de ideias cuja relação não é explicada e pelas citações que suportam teor erótico.

Luzes do Cambucí pelas noites de crime...

Calor!... E as nuvens baixas muito grossas,

feitas de corpos de mariposas,

rumorejando na epiderme das árvores...

[...]

Num perfume de heliotrópios e de pôças

gira uma flor-do-mal... Veio do Turquestan;

e traz olheiras que escurecem almas...

Fundiu esterlinas entre as unhas roxas

nos oscilantes de Ribeirão Preto...

$[\ldots]$

Um mulato cor de oiro,

com uma cabeleira feita de alianças polidas...

Violão! "Quando eu morrer..." Um cheiro pesado de baunilhas

oscila, tomba e rola no chão...

Ondula no ar a nostalgia das Baías... 


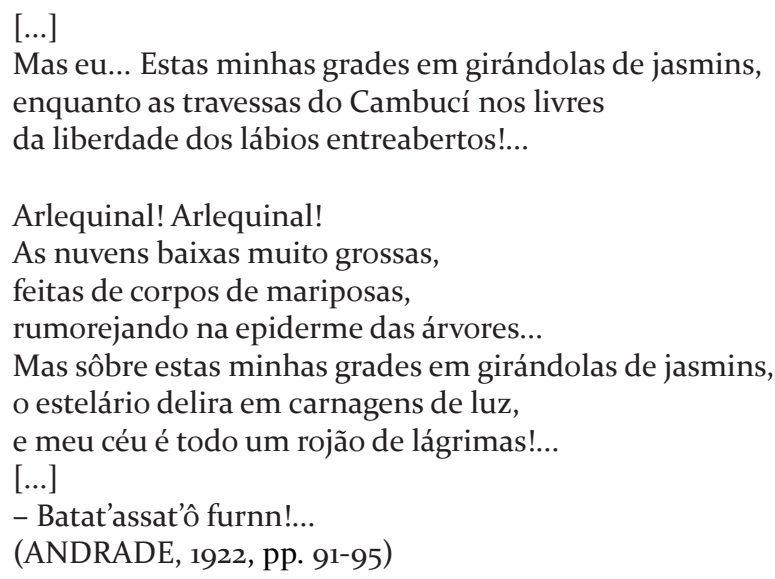

"Nuvens", "feitas decorpos", "perto dasárvores” são termos eexpressões que evocam a natureza na estância com função de mote. O duplo sentido relacionado às práticas sexuais, incluindo as homoeróticas, é factível: perto da "epiderme", quando se encontram aquelas coisas "baixas muito grossas" feitas de "corpos", ali, na "noite do crime" faz "calor". "Mariposas" é referência à prostituição feminina.

No poema, a cor do mulato remete a riqueza e arte ("oiro" foi usado para dourar imagens), o cabelo do mulato alude à sua identidade social, seu corpo tem cheiro intenso e agradável, canta, carrega o violão e tomba talvez o imigrante estivesse bêbado ou cansado demais depois da noite de farra ou trabalho. A relação entre música, negritude e homossexualidade é inteligível no poema "Cabo Machado", de Losango cáqui (ANDRADE, 1926a). Fernando Pérez (2015, pp. 237-238, tradução minha) analisa as maneiras atribuídas à personagem, a forma "[...] sincopada, de marcha irregular, com muito de feminino (por exemplo, o olhar melindroso, coquete, feito de lado quando avança), e a estrofe seguinte prolonga essas conotações em alusão à sua delicadeza, cerimoniosa (ou servil) educação francesa, sua doçura e suavidade". ${ }^{17}$

$\mathrm{O}$ amor tem pelo menos duas vertentes, desejo de ser e desejo de ter: a identificação com a cor ressignificada positivamente e como desejo de posse. A "cor de oiro" do mulato de "Nocturno" reaparece em "Cabo Machado": "Entreabre a boca encarnada num sorriso perpétuo/ Adonde

17 "[...] sincopada, irregular de marchar, que tiene mucho de femenino (por ejemplo, la mirada melindrosa, coqueta, que lanza hacia los lados al avanzar), y la estrofa siguiente prolonga esas connotaciones aludiendo a su delicadeza, su ceremoniosa (o servil) educación francesa, su dulzura y suavidad" (PÉREZ, 2015, pp. 237-238). 
alumia o Sol de oiro dos dentes/ Obturados com um luxo oriental" (ANDRADE, 1926a, [s.p.]). Se "Sol" representa o amor ${ }^{18}$ e "oiro" é a ressignificação orgulhosa e duplicada da cor do mulato (ser e ter), pode-se dizer que o poeta reforça a identidade negra e o afeto entre homens: na passagem de "Nocturno" a "Cabo Machado", o aspecto fracamente delineado ganha definição.

Na carta a Augusto Meyer, de 20 de maio de 1928, Mário de Andrade (1968, p. 52) relata que o poema "Nocturno" é "Influência duma noite pasmosa de ardor sexual procurando uma mulherzinha no bairro do Cambucí". Escrita para Manuel Bandeira em 1929, outra carta dá a entender que, se Mário não participava de atos resisitentes ao socialmente lícito, pelo menos visitava lugares onde isso acontecia. ${ }^{19}$ Ele é paternalista ao referir-se às pessoas que não vivem com boas maneiras ("gente dura"), mas manifesta empatia, em versão não autoritária daquele paternalismo:

\begin{abstract}
Manu
três horas duma noite que além de ser noite de sábado, está de neblina formidável. Noite de sábado já é uma das coisas mais humanas de São Paulo, todos os húngaros, tchecos, búlgaros, sírios, austríacos, nordestinos saem passear, gente dura, no geral tipos horrorosos, mas me sinto bem no meio deles. E além disso: a neblina, um fog maravilhoso. No Anhangabaú não se via nada [...] Então voltei procurando caminhos mais misteriosos, cheguei a ter medo no meio do parque Pedro II, completamente sem iluminação e com alguns ruídos nas moitas. Depois atravessei o bairro turco e só quando esbarrei na estradade-ferro, vim me encostando nela até esta rua Lopes Chaves. Muito apito de trem, várias propostas de aventuras, uma calma interior sem comparação, o espírito vivinho gozando em colher. Mas cheguei meio excitado, sem sono, e estou escrevendo. (ANDRADE; BANDEIRA, 200o, p. 427)
\end{abstract}

Em “Nocturno" a sobreposição de imagens, a falta de relação explícita entre elas e algumas frases herméticas tornam alguns sentidos difíceis de perceber. O tropo reúne e expõe imagens da margem social: a prostituição feminina, o andar noturno e o aspecto ameaçador se aproximam às alusões eróticas e homoeróticas.

$18 \mathrm{O}$ argumento é explicado no tropo $O$ medo incita o desejo.

19 O passeio noturno em outro contexto da obra de Andrade: "o desenvolvimento do poema ["Canto do mal de amor"] constitui um aprofundamento da consciência em direção aos grandes conflitos inconscientes, revelados no instante em que a caminhada solitária pela noite transforma-se no inferno simbólico da tortura, da mutilação e da castração, obsessivamente vividos e/ou fantasiados" (LAFETÁ, 1986, p. 41). 


\section{CONGRESSO DE MARGINAIS}

"Marginal" tem conotação pejorativa ao fazer referência à marginalidade e ao crime: fabrica-se conjunto de imagens associadas à pobreza; e o homoerotismo também é parte do conjunto de atitudes, pessoas e grupos estigmatizados. No imaginário das elites se observa a seguinte constelação: “[...] desde a famosa 'costureirinha', a operária, a lavadeira, a empregada doméstica, a doceira, até a florista e a artista, as várias profissões femininas foram sempre estigmatizadas e associadas à imagens de perdição moral, degradação e de prostituição" (RAGO, 2009, p. 226). Essa estigmatização é explicada na seguinte análise, de obra e autor anteriores à época aqui tratada:

\footnotetext{
Nesse sentido, como veremos no romance $O$ cortiço [1888], o homossexual só é dado como marginal e, por isso, espancado, no momento em que se transpõem as fronteiras da comunidade popular [diferente da família nuclear burguesa], para entrar em contato com a burguesia. (SANTIAGO, 2008, p. 197)
}

Para Santiago existe contraposição entre a "solidariedade" na comunidade popular e a "privacidade" das famílias abastadas. A privacidade seria uma ideia de classe (2008, pp. 198, 197). Em análise sobre São Paulo, o sociólogo Barbosa da Silva (1959, p. 351) nomeia esse conjunto de "regiões morais" e explica que "a área de desorganização aparece como inclusiva da área de concentração de homossexuais". E continua, "essa mobilidade social, acompanha e intensifica uma grande mobilidade moral. É a zona de maior variedade de religião, cultural, sentimentos políticos, nacionalidade, cor, raça, etc." (p. 353). Para ele, a percepção da existência de homossexuais na sociedade é evidente: homossexuais atuam como heterossexuais para serem aceitos pela sociedade. E os homossexuais reconhecem outros com características semelhantes: gestos, roupas, maneiras de falar ou andar (pp. 357 e 355).

Em Homosexualismo e endocrinologia, do médico Leonídio Ribeiro (1938), a relação entre homossexualismo e pobreza se encontra no modo de seleção das pessoas. O autor entende que vai esclarecer a "biologia do homem criminoso" (p. 7). E relata que não foram nem médicos, nem biólogos ou antropólogos, mas sim a polícia civil que deteve 195 indivíduos por prática habitual de "pederastia passiva" no Rio de Janeiro (p. 8). Essas pessoas foram levadas ao Laboratório de Antropologia Criminal e, a partir do crivo policial, Ribeiro fez os exames biométricos 
e lombrosianos. ${ }^{20}$ Existem dados dos detidos pela polícia de São Paulo, no relatório "Contribuição ao estudo dos homossexuais", do psiquiatra do Instituto de Identificação, Edmur de Aguiar Whitaker (1937), publicado nos Annaes da Primeira Semana Paulista de Medicina Legal e no "Estudo biográfico dos homossexuais (pederastas passivos) da capital de São Paulo” (WHITAKER, 1939). Deduz-se que homossexuais de grupos privilegiados não eram selecionáveis pela polícia.

Em texto de 1942, O novo Código Penal e a medicina legal, Ribeiro (1942, p. 121) explica que a sensibilidade à dor por seres inferiores é menor, pessoas inteligentes sofrem mais: "É ainda o grau inferior de inteligência que explica porque o selvagem e o sertanejo são quase indiferentes às dores, enquanto o homem civilizado é tão sensível". O "outro" é mais insensível à dor por ser menos humano, menos inteligente. Entre os nomes que autorizam esses argumentos, o autor menciona as ciências de Lombroso, Mac-Donald e Charles Richet. Na interpretação de Ribeiro (p. 123), o "outro", além do sertanejo, pode incluir o indígena, toda a variedade de doentes mentais, japoneses, indianos, chineses etc. Quando o autor estabelece a comparação entre "operários" e "intelectuais", os "médicos" surgem como os "mais sensíveis". Ele conclui essa seção com elogios à comissão revisora do novo Código Penal por ter eliminado "dor" do texto: dor é "heresia científica"; em vez disso, o uso de "lesão" teria a eficiência de implicar a verificação "material" dos fatos (p. 141). O discurso que dá conotação racial a classe, sexo e outros não reconhece os efeitos da violência simbólica, porque esta é a sua competência.

No caso de Mário de Andrade, o extremo no qual o popular suporta associações positivas com a marginalidade manifesta-se em cartas a Drummond de Andrade. Aquilo que é produzido pelo "povo" contrasta com a erudição e a supera:

E então parar e puxar conversa com gente chamada baixa e ignorante! Como é gostoso! Fique sabendo duma coisa, se não sabe ainda: é com essa gente que se aprende a sentir e não com a inteligência e a erudição livresca. (ANDRADE; ANDRADE, 2002, p. 48)

Com a gente baixa você tem muito que aprender embora não pra bancar o primitivista, é lógico. (ANDRADE, 1926, p. 1)

20 O médico Cesare Lombroso (1835-1909) acreditava que a criminalidade é fenômeno físico e hereditário. Características físicas determinariam comportamentos. Suas ideias obtiveram grande influência na antropologia criminal. 
[...] sempre falei com escândalo de todos que jamais um compositor erudito inventou musicas tão bonitas como certas coisas do povo. (ANDRADE, 1927, p. 1)

Elizabeth Travassos explica que Mário tende a operar com categorias íntegras de "erudito e popular", em oposição a "semicultura e cultura popularesca”, seus "negativos sinistros” (1997, pp. 7 e 116). Esse sentido de popular atribui ao outro certa totalidade positiva que o enunciador não pode ter e necessita recuperar, o que se observa nas citações acima. Chega a ser o inverso lógico da operação de Ribeiro, aquela que fabrica o outro em vários graus de abjeção permanente. Mas Mário não insistiu em atribuir ao outro o positivo absoluto. Ele escrevia e se correspondia com pessoas que careciam valorizar esse outro. Em discussão ao longo da correspondência com Drummond, Mário reclama da atitude do amigo, que despreza tudo o que pode ser brasileiro, enquanto admira e se identifica com a cultura francesa. Drummond responde: "Detesto o Brasil como a um ambiente nocivo à expansão do meu espírito. Sou hereditariamente europeu, ou antes: francês" (ANDRADE; ANDRADE, 2002, p. 59). Na mesma carta ele cede ao argumento de Mário.

No "Prefácio Interessantíssimo" (ANDRADE, 1922, p. 34), ele inclui o tema dos ausentes e infelizes na preparação da universalidade artística, e dá importância ao sofrimento e ao fracasso: "Reconheço mais a existéncia de temas eternos, passíveis de afeiçoar pela modernidade: universo, pátria, amor e a presença-dos-ausentes, ex-gôso-amargo-de-infelizes”. Apesar da pluralidade de subalternos e do caráter engajado de Paulicea, esta não foi percebida como solene ou trágica: "Se a blague é produtiva nas artes, o poeta não é necessariamente sisudo e sofredor" (TRAVASSOS, 1997, p. 35).

Em "Nocturno", junto ao lugar onde homens buscam sexo, Mário desenha personagens e situações marginais ao lado das figuras da modernidade de São Paulo: o sotaque do vendedor de batatas: “Batat'assat'ô furnn!..., o violão, o mulato "cor de oiro", os pares de enamorados, a prostituição feminina ("Balcões na cautela latejante, onde florem Iracemas/ para os encontros dos guerreiros brancos... Brancos?" (ANDRADE, 1922, p. 94) ao lado dos bondes e luzes da cidade. O homoerótico é outro traço na composição de situações justapostas ao progresso, à burguesia, à oficialidade. ${ }^{21}$

21 Artigos publicados em jornais entre 1921 e 1926 dão indícios do porquê a poesia de Mário incomodou. Ver o caso da Folha da Noite (VERGARA, 2018). 
A repressão policial é tema nos textos de Mário. Na segunda estrofe de "Paisagem N. 1", a guarda cívica prende "São Bobo", quando este canta seu "tralálá" (ANDRADE, 1922, p. 64). Os termos que o poeta escolheu para o agente e a prática musical indicam o cotidiano, e não a exceção, e implicam um agente fora da posição de poder e sem reconhecimento social. A crítica ao autoritarismo necessita reconhecer as relações de força. Então o poeta questiona se "prisão" é condição de possibilidade de "civilização": responde que a tristeza pessoal acompanha o espaço público atemorizado ("o cinzento das ruas arrepiadas"). Em "Danças dramáticas do Brasil”, o texto musicológico citado a seguir, Mário de Andrade acusa o "preconceito de cidade moderna", cuja "boa educação" vigia as práticas alheias à cultura oficial, e especifica as formas musicais perseguidas pela polícia e pelo preconceito social.

A civilização criou o preconceito de cidade moderna e progressista, com boa-educação civil. E como em Paris, Nova York e São Paulo não se usa danças dramáticas, o Recife, João Pessôa e Natal perseguem os Maracatús, Caboclinhos e Bois, na esperança de se dizerem policiadas, bem-educadinhas e atuais. São tudo isto, com cheganças ou sem elas. Mas quem que pode com o delírio de mando dum polícia ou dum prefeito, ou com a vergonha dum cidadão enricado que viajou na avenida Rio Branco! Cocos viram besteira, Candomblé é crime, Pastoril ou Boi dá em briga. Mas ninguém não lembra de proibir escravizações ditatoriais, perseguições políticas, e ordenados misérrimos provocadores de greves que de tudo isso nasce crime e briga também. (ANDRADE, 1946, p. 95)

Mário sublinha a incapacidade de questionar a autoridade e o apagamento subserviente das responsabilidades dos governantes em prol da criminalização dos subalternos. Na década de 1940, ele havia montado sua rede de correspondência com interlocutores de muitas partes do Brasil, havia feito viagens etnográficas no interior do país, conhecia as práticas populares em vertentes musicais e literárias, tinha sido empossado e demitido do Departamento de Cultura de São Paulo, e, depois de 25 anos de atividade, finalizou seu texto póstumo com a denúncia da associação entre "progresso", "educação" e "atualidade" e a erradicação de práticas culturais subalternas. E ele insiste sob outro ângulo: "Mas também as civilizações evitam com cuidado criar o conceito de felicidade, que desse lado é que estão os Caboclinhos e Congados... A decadência das danças dramáticas é 'estimulada' pelos chefes, o seu empobrecimento é 'protegido' pelos ricos" (ANDRADE, 1946, p. 95). Felicidade não pode incluir o que é produzido pela associação entre educação e policiamento ou civilidade e criminalização, a ideia é outra: é aquilo que o povo faz quando deforma 
práticas e discursos, matéria do artigo. Segundo ele, as práticas erradas e em algum grau autônomas que ele observa no "povo" são as que constróem essa felicidade.

O conceito de popular em Mário de Andrade contém exclusões. Em Aspectos da literatura brasileira, ele se propõe encontrar o popular no erudito e comenta: "Expressão popular em artista culto não há, porque a alma danada de Gregório de Matos não tinha a menor possibilidade de o ser" (ANDRADE, 1972, p. 111). A menção aponta o silenciamento ou abrandamento das imagens de obscenidade:

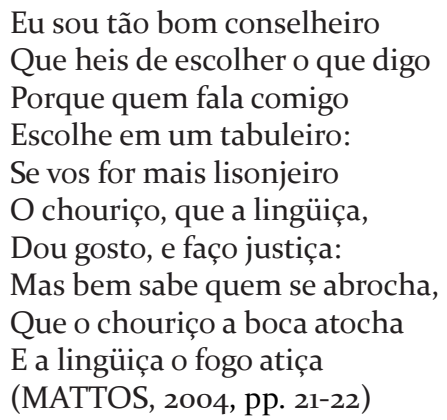

Porque Mário suaviza o obsceno? Este faz parte das práticas populares e seu uso erudito é antigo. Em Namoros com a medicina, ele escreve com erudição sobre excrementos, em citações de frases do populário brasileiro e português, e não tem coragem de grafar a palavra "cu", que aparece muitas vezes através da letra “c.” (ANDRADE, 1939, p. 90, passim). Na suavização do obsceno rejeita-se a expressão crua do sexo e faz-se associação com certas condições do corpo: doenças, envelhecimento e morte. Que essa atitude esteja relacionada à classe social, que a sensibilidade não popular contribua para a suavização do obsceno e que a norma culta o exclua, são opções a se considerar. De qualquer forma, a homofobia internalizada é vergonha autoassumida, vergonha de se expor inteiramente enquanto sujeito do estigma. Permite entender a suavização do obsceno associado ao homoerótico, pois estigmatizados insinuam não só para se proteger, mas também para se comunicar entre si ou para subverter a ordem de forma indireta. Tratar o assunto com tanto cuidado é um vestígio de homofobia, que se transforma em vergonha de se expressar além da etiqueta. Já que o assunto indizível haverá de ser articulado, que o seja de maneira elevada. 


\section{O MEDO INCITA O DESEJO}

Certo uso do termo "frio" é distinto daquele que descreve São Paulo. Neste caso, "Frio" alude ao medo. A construção sugere algo que está fora da lei, tema que volta valorizado nos escritos de Mário: "Nós hoje nos debatemos sofridamente ante os problemas do homem e da sociedade, com uma consciência, com um desejo de se solucionar, de conquistar finalidade, com um desespero pela posição de fora-da-lei inerente ao intelectual de verdade" (ANDRADE, 1943, p. 70). Em "Paisagem N.1", as imagens que o evocam o frio estão dispersas ao longo do poema e conectadas a elementos positivos: "neve" ligado a "perfumes no ar", ou então o "friozinho... dá uma vontade de sorrir". A pintura de sentimentos é ambígua pela oscilação entre tristeza e alegria.

Minha Londres das neblinas finas!

Pleno verão. Os dez mil milhões de rosas paulistanas.

Há neve de perfumes no ar.

Faz frio, muito frio...

E a ironia das pernas das costureirinhas

parecidas com bailarinas...

O vento é como uma navalha

nas mãos dum espanhol. Arlequinal!...

Há duas horas queimou Sol.

Daquí a duas horas queima Sol.

Passa um São Bobo, cantando, sob os plátanos,

um tralálá... A guarda-cívica! Prisão!

Necessidade de prisão

para que haja civilização?

Meu coração sente-se muito triste...

Enquanto o cinzento das ruas arrepiadas

dialoga um lamento com o vento...

Meu coração sente-se muito alegre!

Este friozinho arrebitado

dá uma vontade de sorrir!

E sigo. E vou sentindo,

á inquieta alacridade da invernia, com um gôsto de lágrimas na boca...

(ANDRADE, 1922, pp. 63-65)

O matiz positivo de "arlequinal" associado à navalha ou ao espanhol gera ambiguidade nesses versos. Se a personagem evoca certo assaltante, imigrante ilegal ou parceiro sexual (o vento foi comparado à navalha, 
símbolo fálico), importa menos que a sugestão de personagens marginais atraentes porque perigosas, reforçada pelo uso da figura do frio paulista como amável. "Arlequinal" alude à personalidade fragmentada ou inconsistente, imagem forjada por Mário em Paulicea. Cada parte dessa personalidade tem sua própria libido, então pode-se supor que o meliante induz medo e desejo. A oposição de termos (alegria / tristeza) e a mescla de opostos e complementares (vento+navalha / arlequinal / sol) arquiteta isso. Pode-se interpretar como irônica a figura da libido pelo frio, pelovento ou pelos marginais, porque são formas de dizer que o abjeto é ruim. Mas a leitura dos poemas de Paulicea permite questionar essa interpretação, ao notar a identificação do poeta com os subalternos e pela zombaria aos administradores do poder: deputados, burgueses, milionários.

Percebe-se o uso característico de "lágrimas" no poema "Nocturno" e "Paisagem N.1". Em "Paisagem N.1" esse uso se refere ao frio, em "Nocturno" o duplo sentido resulta da ligação de "lágrimas" com a paisagem celeste, na estrofe em que se atribui carnalidade à luz: "o estelário delira em carnagens de luz,/ e meu céu é todo um rojão de lágrimas!...”. As "girândolas de jasmins" associam-se a "rojão", e esse mesmo verso na estrofe anterior, é seguido doutro que elogia a "liberdade dos lábios entreabertos!..." no Cambucí (ANDRADE, 1922, p. 94). "Lágrimas” pode apresentar conotação positiva ou negativa. É positiva na figura em que a dor é boa ou naquela em que a luz do Cambucí produz liberdade, e a liberdade é algo que se constrói em luta contra o instituído, assim, Cambucí liga-se ao crime em todos os versos. A repressão é benéfica, caso se entenda que as grades oferecem proteção contra aquilo que a maioria faz e instauram o ponto de vista privilegiado: “Todos embarcam na Alameda dos Beijos da Aventura!/ Mas eu... Estas minhas grades em girândolas de jasmins [...]”. Na última estrofe de "Paisagem N.1", as contraposições se condensam: "inquieta alacridade da invernia" sentida no "gosto de lágrimas na boca” indica não apenas que a repressão seja benéfica, mas que o sofrimento também o seja. Sofrimento e repressão podem permitir que o sujeito aprenda a ler o mundo de modo particular e distinto.

Em "Paisagem N. 3", o tropo do frio surge junto a imagens de ocultação e aparência:

Chove?

Sorri uma garôa cor de cinza, muito triste, como um tristemente longo...

A casa Kosmos não tem impermeáveis em liquidação...

Mas nêste largo do Arouche 
posso abrir o meu guarda-chuva paradoxal, êste lírico plátano de rendas mar...

Ali em frente... - Mário, põe a máscara!

- Tens razão, minha Loucura, tens razão.

O rei de Tule jogou a taça ao mar...

Os homens passam encharcados...

Os reflexos dos vultos curtos

mancham o petit-pavé...

As rôlas da Normal

Esvoaçam entre os dedos da garoa...

(E si pusesse um verso de Crisfal

No De Profundis?...)

De repente

um rádio de Sol arisco

risca o chuvisco ao meio

(ANDRADE, 1922, pp. 105-106)

Na primeira estrofe, a aparência é fumaça, pois a garoa não é neblina: "garôa cor de cinza". Na segunda, a Loucura propõe o uso da máscara, a atuação e ocultação. Na terceira, as pombas ocupam o vazio que há entre os dedos da garoa. No início o poeta contenta-se com seu paradoxo: o guarda-chuva não protege da água, é feito de líquido, rendas que não cobrem da chuva, seu "lírico plátano". As duas primeiras figuras e a fumaça aludem ao artificial, em oposição à natureza, e ao anormal, evocação do que não tem função ou não éajustado. A taça jogada ao mar implica a lenda do rei $^{22}$ que não pode ou não quer mais praticar os excessos libertinos da juventude, então ele atira ao mar a taça com as lembranças libertinas e a força delas. Pode-se supor que o excesso lançado ao mar contamine as figuras aquáticas (garoa, chuva, encharcado, chuvisco). A figura do frio, além de aludir ao medo, estará conectada ao excesso. A relação entre as estrofes é hermética.

A maioria das referências a De profundis nos jornais paulistas, entre 1910 e 1919, corresponde aos versos latinos do Salmo 130. Poucos casos são referência a anúncios do livro de Wilde. Não foi possível imaginar interpretação que integrasse o salmo no poema comentado. Todavia, certa apologia da homossexualidade foi publicada: no jornal Hoje, Vinicio da Veiga (1921, p. 10) ${ }^{23}$ escreve que "o amor de uma pessoa por

22 Ver a versão de Goethe (1856) ou de Almeida (1946).

23 Veiga, que foi diplomata brasileiro na Alemanha, mostra interesse no feminismo, socialismo e sexualidade. No seu romance, $O$ homem sem máscara: pathologia social, 
outro do mesmo sexo póde ser, debaixo das considerações da sciencia, sexualmente normal: quer dizer, limpo, claro e nobre", e cita a opinião de "altas personalidades intellectuais" como Sócrates ou Wilde. Wilde ficou conhecido pelo seu escândalo homoerótico com Alfred Douglas: em 1895 a justiça inglesa condenou-o por sodomia a dois anos de trabalhos forçados na prisão de Reading, onde escreveu De profundis. O texto de 1897 só foi publicado integralmente em 1949. No poema de Mário, a frase "verso de Crisfal” remete à poesia amorosa de Cristóvão Falcão (1512-1557). A relação entre Wilde e Falcão implica a condenação da repressão da liberdade amorosa, pois, de modo semelhante ao de Wilde, poemas e cartas foram inventados por Falcão dentro da prisão: no século dezesseis, o pai do trovador o prendeu porque não aceitou o casamento feito por amor - e não pelos interesses socioeconômicos - entre adolescentes de diferente hierarquia social. ${ }^{24} \mathrm{O}$ poema não torna explícita nenhuma das situações, o leitor é que deve averiguar. A figura com a qual o poeta introduz versos românticos nas cartas em que Wilde discorre sobre ódio, ressentimento, sofrimento e arte, não foi escrita apenas para dar a entender algo, é ato de empatia, ${ }^{25}$ à maneira de Mário de Andrade. Não é direto, não é explícito, alude, e não diz.

O efeito final é excepcionalmente enigmático: "De repente/ um rádio de Sol arisco/ risca o chuvisco ao meio". As vogais com grafia fálica geram assonância e as palavras utilizadas completam a referência ao fálico. "Chuvisco" alude à imagem menos fálica, as gotas de chuva que caem. Risca ou risco, traço ou fazer traços. O termo "arisco" contém "risco" e se refere àquele que rejeita carinho ou é áspero, sentido que implica certa masculinidade. Rádio pode denotar raio, imagens desenháveis por traços. "Rádio" é a metade do diâmetro, mas também é o osso que junto ao cúbito forma o antebraço, estrutura de dois ossos paralelos. O sentido do rádio que "risca o chuvisco ao meio" é o do calor que rasga o frio, mas a

explica: "O meu livro é uma expressão esthetica d'analyse applicada ás degenerescencias sexuaes e do caracter, deste seculo de decadencia e fraquezas hereditarias, em que as raças succumbem sem força e sem belleza" (VEIGA, 1921, p. 14). Ele usa conceitos da criminologia, mas trata tais características como perfeitamente humanas.

24 "Ao idylio doloroso das duas crianças deliciosamente narrado nas Trovas do pastor Chrisfal, veio a Carta, publicada em sequencia da Egloga em Ferrara em 1554, revelar-nos que o ingenuo namorado estivera prezo cinco annos por motivo d'essa aventura" (BRAGA, 1915, p. 146).

$25 \mathrm{Na}$ teoria queer e na análise do discurso, a interpretação inclui o sentido textual e o efeito da atuação deste (LOZANO, 2002, p. 61; SALIH, 2012, p. 124). 
implicação não se completa. Há, assim, figuras de coisas que não são o que parecem, cujo significado não se torna explícito.

"Sol" com maiúscula aparece várias vezes em Paulicea de forma hermética. Na "Ode ao burguês": "Fará Sol? Choverá? Arlequinal!/ Mas à chuva dos rosais/ o êxtase fará sempre Sol!", ou em "Paisagem N.1”: "O vento é como uma navalha/ nas mãos dum espanhol. Arlequinal!.../ Há duas horas queimou Sol/ Daqui a duas horas queima Sol" (ANDRADE, 1922, pp. 68, 63). Se as imagens não se percebiam relacionadas, agora, pela presença de "Sol" nos dois poemas, nota-se a associação entre a navalha que corta e o rádio que risca; ainda, da mesma forma que "rádio", "navalha” suporta o sentido de duas efígies fálicas reunidas. ${ }^{26}$ Ao analisar a poesia de Mário, Nelly Novaes Coelho (1970, p. 151) oferece explicação para o uso de "Sol":

[...] (“deixo que meu olhar te conceda o que é teu... carne que é flor de girassol”). Nesta última imagem vemos repetir-se uma identificação muito cara ao nosso poeta, e que êle usa com as mais diversas conotações: o amor ligado à idéia de sol. Sendo, pois, o amor um sol, o corpo da amada é uma flor que para êle se volta, atraída irresistívelmente como o girassol.

"Carne" se relaciona primeiro a corpo e sexualidade, e, através dessa figura, faz sentido ligar seu significado ao "amor". Na hipótese de que o tema seja o amor, a alusão a este após a referência a De profundis, e ligada a figuras fálicas, reforça a intensidade da imagem que põe versos de amor nas cartas de Wilde. O fato de que "Sol" aluda ao sexual, deixa as evocações mais gráficas (círculos, traços, cortes). No poema "Paisagem N.1", "Sol” fortalece o aspecto positivo do desejo pelo marginal, o calor que suaviza o medo e o frio. A estranheza da construção sem sujeito ("queimou Sol") e o espelhamento do duplo nas frases temporais (há/ daqui; duas horas/ duas horas; queimou Sol/ queima Sol) sublinha o enigma. A poesia concentra figuras e nega a conclusão do sentido. ${ }^{27}$

Mário alude a significados não compreensíveis sem mediação. Ele não prescreveu conceitos acabados ou formulações definitivas, ele analisa e levanta seus temas sem sistematizar. Utilizou fórmulas como "fluidez musical da palavra" para dar a entender o sentido ambíguo ou

26 No Aurélio, o termo navalha é definido como: "instrumento cortante, que consta de uma lâmina e de um cabo com dispositivo para resguardar o fio da mesma lâmina”.

27 "Estruturas elípticas demandam que o leitor crie sua própria continuidade de sentido e emoção" [Elliptic structures demand that the reader create his own continuity of meaning and emotion] (FOSTER, 1965, p. 81, tradução minha). 
indeterminado (ANDRADE, 1972, p. 116). Nesse sentido arregimenta a palavra "tresler": ler errado, ler ao contrário, enlouquecer por ler muito, perder o juízo: "Só em poesia verdadeira é que se pode adquirir toda a riqueza e o orgulho do verbo 'tresler'. Poesia legítima não se lê, se treslê. Só quem sabe tresler, tresloucado amigo, é capaz de ouvir e entender estrelas" (pp. 117-118).

A repressão benéfica ganha variação, porque Mário escreve que é necessário ser capaz de desconectar o aprendizado. A repressão é negativa quando os sujeitos se acomodam ao instituído. Ele escreve em Aspectos da literatura brasileira que o medo do amor e o medo da realização sexual desse amor são fantasmas que perseguem os rapazes: a repressão é importante na formação da identidade do sujeito e comum no Brasil, que, apesar da fama de liberal, é conservador. Mário afronta isso ao escrever que o povo "tem por sexo a paciência" (ANDRADE, 1972, p. 25). Há uma ligação autobiográfica com essa palavra: "Frederico Paciência” é o nome duma narrativa homerótica de Contos novos (ANDRADE, 1947). Ele começou a escrevê-la dois anos após a publicação de Paulicea, e, após vinte anos de elaboração, pediu a seu editor que a publicasse somente depois de sua morte. Não quis saber da recepção desse texto em vida. O autor chama atenção para o uso do referido vocábulo no final do conto. Ele elabora e assume sua própria identificação com a palavra:

- Paciência, Rico.

- Paciência me chamo eu!

Não guardei êste detalhe para o fim, pra tirar nenhum efeito literário, não. Desde o princípio que estou com êle pra contar, mas não achei canto adequado. Então pus aqui porque, não sei... essa confusão com a palavra "paciência" sempre me doeu mal-estarentamente. Me queima feito uma caçoada, uma alegoria, uma assombração insatisfeita. (ANDRADE, 1947, p. 121)

O narrador enfatiza a presença constante da alegoria ("Paciência me chamo eu!") e a julga óbvia. A comparação de textos de procedência diversa torna o signo distinto: "Mário de Andrade inventou a figura do Boi Paciência e que o conto 'Frederico Paciência' já existia com esse nome antes da publicação de Girassol [da Madrugada]", e neste último o "tema homossexual” apresenta "identificação cifrada” (RABELLO, 1999, pp. 215, 214). Em Girassol, "Eclipse, boi que fala, cataclisma" correspondem à existência de "algo oculto" que deixa rastros, ao boi que retorna depois de morto e ao poder devastador de Eros. Bandeira pediu a Mário que mudasse o verso original (hoje desconhecido) por causa do seu teor 
homoerótico (MORAES, 2015, [s.p.]). Na hipótese apresentada aqui, não se pode esconder que certa forma textual foi gerada pelo medo de expor as ideias ao entorno social. Esse conto e alguns poemas de Paulicea podem ser explicados através do homoerotismo ou homoafetidade, mas a homossexualidade não é nomeada e não se define. Dois rapazes manifestam amizade profunda e essa amizade poderia levar à atividade sexual. Não acontece. Mário não indica a homossexualidade como algo conclusivo. Sugere algo que não nomeia e está no centro da interpretação do real. Parte importante do que sentiu escapa ao que foi escrito e à interpretação dele, mas pode-se imaginar a coação que sentiu ao cifrar a escritura póstuma com tanto cuidado.

Mário usa o termo "sol" no conto "Frederico Paciência" de forma a revelar seu código. No início, a admiração moral e física de Juca (alter ego de Mário) por Frederico sintetiza-se na expressão "solaridade escandalosa”, a soma dos atributos admiráveis e desejáveis: "Não era beleza, era vitória" (ANDRADE, 1947, p. 99). O admirador se funde com o objeto de identificação e desejo: "Quis ser êle, ser dêle, me confundir naquele esplendor, e ficamos amigos" (p. 10o). Depois que a amizade se estabelece, Juca quer que o outro abandone a "infância" e lhe empresta a História da prostituição na antiguidade, porque almeja que Frederico tenha "certas revelações" sexuais (pp. 105-106). Este fica perturbado com a leitura, e Juca nota o consequente afastamento emocional do colega. A intensidade da separação merece signos especiais: o "sol" surge entre eles, luminoso eclipse.

Me falou um bom-dia simples mas que imaginei tristonho, preocupado. Mal respondi, com uma vontade assustada de chorar. Como que havia entre nós dois um sol que não permitia mais nos vermos mùtuamente. Eu, quando queria segredar alguma coisa, era com os outros colegas mais próximos. Êle fazia o mesmo, do lado dêle. Mas ainda foi êle quem venceu o sol. (ANDRADE, 1947, p. 105)

A "amizade assim tão agressiva" entre eles se consolida e gera gracejos homofóbicos, coisa que ambos rebatem com violência física (ANDRADE, 1947, p. 107). Frederico foi a "vitória” e depois venceu o eclipse, mas, após desafiar e golpear o ofensor, Juca fabrica sua própria força:

Fui embora compassado. Tinha também agora um sol comigo. Mas um sol ótimo, diferente daquele que me separa de meu amigo no caso do livro. Não era glória nem vanglória, nem volúpia de ter vencido, nada. Era um equilíbrio raro - êsse raríssimo de quando a gente age como homem-feito, quando se é rapaz. Puro. E impuro. (ANDRADE, 1947, p. 109) 
Nesse caso não há admiração ou separação, não se representa a unidade com o ser amado, o amor ou a perfeição; há referência à maturação pessoal ou à prática do aprendizado de si, construídos com e contra o saber instituído. O terceiro uso ofende a conjunção de angústia, impotência e medo que o termo "paciência" aponta no final do conto. $\mathrm{O}$ terceiro representa a coragem.

\section{NORMALIDADE CATIVA}

Em Ode ao burguês, o termo "ódio" expressa o desejo de ruptura com a ordem, tradição ou burguesia. Na Semana de Arte Moderna, o poema provocou rejeição na plateia (BRITO, 1968, p. i). Em carta a Drummond, de 8 de maio de 1926, Mário alega que todos os seus alunos de piano o abandonaram. Caso não tivesse emprego vitalício, teria ficado sem renda (ANDRADE, 2002, p. 215). A masculinidade se revela no serem as atitudes burguesas instrinsecamente masculinas, principalmente porque a vida pública era vedada às mulheres. A sátira relaciona o fato de o burguês ter medo do novo e erguer sua autoconfianca na outorga de crédito exagerado à tradição de consumo e status social, sua prisão consentida:

Eu insulto o burguês! O burguês-níquel,

O burguês-burguês!

A digestão bem feita de São Paulo!

O homem curva! o homem-nádegas!

O homem que sendo francês, brasileiro, italiano,

é sempre um cauteloso pouco-a-pouco!

$[\ldots]$

Eu insulto o burguês-funesto!

$\mathrm{O}$ indigesto feijão com toucinho, dono das tradições!

Fóra os que algarismam os amanhãs!

Olha a vida dos nossos setembros!

Fará Sol? Choverá? Arlequinal!

Mas á chuva dos rosais

o êxtase fara sempre Sol!

[...]

Come! Come-te a ti mesmo, oh! gelatina pasma!

Oh! purée de batatas morais!

Oh! cabelos nas ventas! oh! carecas!

Odio aos temperamentos regulares!

Odio aos relógios musculares! Morte e infámia!

(ANDRADE, 1922, pp. 67-68)

É sintoma do grupo criticado que as práticas culturais manejadas por mulheres devam ser menos significativas, enfeite para ludibriar, exibição 
simplória: "para dizerem que as filhas da senhora falam francês/ e tocam o 'Printemps' comas unhas!' (ANDRADE, 1922, p. 67). O medodo novorecebe vários termos e às vezes aparece fundido ao nome dos grupos dirigentes: "aristocracias cautelosas", "que vivem dentro de muros sem pulos", "dono das tradições!", “morte ao burguês-mensal”. Se o homoerotismo não faz parte da "Ode ao burguês", o sarcasmo do poema implica a erosão das práticas burguesas de sexualidade, aquelas que excluem as mulheres e impõem regras aos homens.

A homofobia coexiste com o homoerotismo no mesmo indivíduo. É uma das partes incoerentes da personalidade. Judith Butler (2007) explica a ficção da ideia de gêneros ou sexualidades coerentes, a ficção de supor que o indivíduo continua igual a si mesmo, ou a ficção de que o sexo, a identidade sexual, a orientação sexual podem ser atravessados por uma linha coerente de práticas. A identidade é ficção que atua sobre a realidade. Essa apreciação decifra o narrador de Paulicea: ao mesmo tempo em que mostra aspectos à margem da sociedade, não sente a exigência de precisão para esses assuntos. A vergonha socialmente insuflada afeta seu modo de retratá-los. Seja pelo medo da incompreensão ou rejeição, seja porque a linguagem é insuficiente para explicar experiências humanas. Nem a linguagem da comunicação nem a produção artística permitem interpretação completa ou coerente.

A rejeição contra si mesmo é constitutiva: "O fato de não poder falar sobre tal assunto [homossexualidade], nem sequer mencioná-lo, só reforça a presença do mesmo no cotidiano" (FIGARI, 2007, p. 16). Mário de Andrade não utiliza o termo homossexualismo ou homossexualidade em nenhum poema. Mas em "Colloque sentimental" relaciona figuras de subalternidade e práticas sexuais reprimidas: chagas dos pés por causa dos espinhos das calçadas, imagem da rotina e banalidade do sofrimento, expressões com sentido extremo e sem definição ("As Babilônias dos meus desejos baixos", "cofres abarrotados de vidas", "cogumelo das podridões" - ANDRADE, 1922, p. 107), aspectos incoerentes do progresso ("espinhos das calçadas", "casacas eruditamente bem talhadas", "E o rouge - cogumelo das podridões" - p. 107) e práticas socialmente reprováveis ("Enriqueceres em tragédias", "lábios pesados de adultério", “desejos baixos" - p. 107). Compõem o poema os lugares da tradição, da erudição, do progresso e do crime paulista, e a novidade musical estrangeira produzida por outro grupo estigmatizado: a "jazz-band da cor". Sem conexão aparente com essa construção, o poeta introduz o diálogo entre dois homens. $\mathrm{O}$ 
primeiro interpela aquele que se declara conde e culto, pergunta-lhe pela existência de bairros pobres e o convida a passear. Depois, transforma-se em dito-cujo discreto ("cale-se"), que faz companhia enquanto aceita gorjeta. "Cale-se" é a negativa ao convite para sair e esquecer a vizinha? Pode-se interpretar nele a afirmação da autoridade de quem paga:

Tenho os pés chagados nos espinhos das calçadas...

Higienópolis!... As Babilônias dos meus desejos baixos...

Casas nobres de estilo... Enriqueceres em tragédias...

Mas a noite é toda um véu-de-noiva ao luar! [...]

O clamor dos cofres abarrotados de vidas...

Ombros nus, ombros nus, lábios pesados de adultério... [...]

- Cavalheiro... - Sou um conde! - Perdão.

Sabe que existe um Braz, um Bom Retiro?

- Apre! respiro... Pensei que era pedido.

Só conheço Paris!

- Venha comigo então.

Esqueça um pouco os braços da visinha...

- Percebeu, hein! Dou-lhe gorgeta e cale-se.

O sultão tem dez mil... Mas eu sou conde! [...]

- Deixe-me pôr o lenço no nariz.

Tenho todos os perfumes de Paris!

- Mas olhe, em baixo das portas, a escorrer...

- Para os esgôtos! Para os esgôtos!

- a escorrer

um fio de lagrimas sem nome!...

(ANDRADE, 1922, pp. 107-109)

Em São Paulo, no início do século vinte, Mooca, Cambuci, Braz e Bom Retiro eram bairros pobres, ao contrário de Higienópolis, higiênico e aristocrático. "Mas era especialmente no bairro do Brás [cerca de 1913] que a escória das meretrizes negras se reunia, como definiam os memorialistas misóginos do período" (RAGO, 2005, p. 101). No tropo congresso de marginais explicita-se a associação entre homossexualidade e pobreza. Ainda:

O baixo meretrício é sempre constituído pela literatura, ou pela documentação em geral, como território do prazer delirante, embora ao mesmo tempo como região fronteiriça com a morte, através de metáforas do "lodo", "charco", 
"esgoto", que exprimem a decomposição orgânica de elementos vivos. (RAGO, 1991, p. 245)

Lacunas de sentido estruturam "Colloque sentimental”. A contradição entre o conde com "perfumes de Paris" e o esgoto sob as portas do bairro ermo em São Paulo. A indefinição do episódio: os homens procuravam algum prostíbulo? Havia prostituição masculina ou eles buscavam certo lugar para fumar ópio? A força do sentido provém da insinuação de alguma coisa, da não completude. A existência dessa linguagem é atribuída ao fato de grupos e pessoas marginalizadas desenvolverem outros códigos para se comunicarem entre si e resistirem à norma social (BOURDIEU, 2011; SEDGWICK, 1998). Se o duplo sentido tem efeito contestador e de comunicação, ele pode ser utilizado para comunicar-se com uns, e não com outros. A produção artística se relaciona com indivíduos desajustados, aqueles cujo desconforto em relação ao social lhes sugere motivos para a criação: “Todos os seres somos fundamentalmente infelizes, e é preciso não esquecer que psicologicamente, em oitenta por cento dos artistas verdadeiros, o próprio fato de serem artistas, é uma definição de infelicidade" (ANDRADE, 1972, p. 90).

"Esgoto" concentra significados abjetos: detrito, não presta, não tem valor. A metáfora pode aludir a qualquer assunto tabu. $\mathrm{O}$ duplo sentido do termo "lágrimas" - a dor e o medo ou a repressão benéfica - está associado ao esgoto e ao silenciamento da identidade. O "esgoto" feito com "lágrimas" ainda se relaciona com a ideia do autor de ser a "chave" de leitura do poema a palavra "sofrer" (ANDRADE, 1922, p. 38): a dor é boa, o sofrimento da repressão beneficia o sujeito. De forma mais direta que a anterior, a falta de identidade implica a homossexualidade, pois a consideração segundo a qual a sodomia é abjeta e nem sequer deveria ser mencionada é conhecida no Brasil desde a época da colônia. ${ }^{28} \mathrm{Em}$ "Colloque sentimental", as alusões homoeróticas se acumulam: o passeio noturno, o medo junto ao desejo, a reunião de marginais. O sentido se condensa na relação de lágrimas, esgoto e sem nome. Essa condensação impede o conforto ou a empatia pela normalidade ou pela adequação social. Esse processo foi observado em outros poemas e de forma mais ou menos velada. Tal modo de estilização poética é testemunho e denúncia

28 Ver Vainfas (2010), Figari (2007), Pieroni (2006). Para Pires de Almeida (1906, p. 4) o assunto é "asqueroso" e "hediondo". Ribeiro (1938, pp. 9-10) escreve que o homossexualismo não é pecado, mas doença mental tratável pela medicina e, em alguns casos, pela polícia. 
de como determinada sociedade condenou certas práticas à vergonha e ao silêncio.

As alusões em Paulicea não se limitam à homossexualidade. De modo geral, incidem sobre a concentração do abjeto, daquilo que é rejeitado socialmente. Além da blague e do caráter de manifesto modernista assumido no momento de sua publicação, Paulicea desvairada carrega os temas que Mário irá desenvolver ao longo de sua carreira: a preocupação com a originalidade na utilização do português, a necessidade do conhecimento e apropriação de novas correntes estéticas, a ênfase na liberdade de pensamento, a urgência do social na arte nacional, e seu interesse por grupos à margem da oficialidade.

\title{
HOMOEROTISM AND SUBALTERNITY IN PAULICEA DESVAIRADA
}

\begin{abstract}
I propose five tropes to relate the manifestations of homoeroticism and those of subalternity in Paulicea desvairada (1922), of Mário de Andrade: amended, impossible, helpless women; night's outing or aim at the danger; marginals' congress; fear nurture desire; and captive normality. In addition to poetic stylization, internalized homophobia allows one to suppose why there is no clear expression of homoerotic ideas and partly explains the rejection of obscene imagery. Stylizations testify to the manner in which society has condemned practices and people to ignominy and silence. Poetic adumbration stirs questionings, thinking and the imagination. With concepts from queer theory, discourse analysis, history, the historiography of homosexuality in Brazil, through research in texts, music and medicine of the time plus the correspondence of Mario, I explore the homoerotic and political theme that lies in the musicologist's poetry.
\end{abstract}

Keywords: Mário de Andrade; Homophobia; Subalternity.

\section{$\overline{\text { REFERÊNCIAS }}$}

ALMEIDA, Fialho de. O país das uvas. Lisboa: Livraria Clássica, 1946[1893].

ALMEIDA, Jose Ricardo Pires de. Homosexualismo: a libertinagem no Rio de Janeiro. Rio de Janeiro: Laemmert \& C., 1906.

ANDRADE, Carlos Drummond de; ANDRADE, Mário de. Carlos \& Mário. Correspondência de Carlos Drummond de Andrade e Mário de Andrade. Leila Coelho Frota (org.). Rio de Janeiro: Bem-Te-Vi Produções Literárias, 2002[1924].

ANDRADE, Mário de. Paulicea desvairada. São Paulo: Casa Mayença, 1922.

ANDRADE, Mário de. O losango cáqui. São Paulo: Tisi, 1926a. 
ANDRADE, Mário de. S. Paulo, 19-III-926. Carta de Mário de Andrade a Carlos Drummond de Andrade, 19/03/1926. Rio de Janeiro: Fundação Casa de Rui Barbosa, 1926b.

ANDRADE, Mário de. S. Paulo-8-V-926. Carta de Mário de Andrade a Carlos Drummond de Andrade, 08/05/1926. Rio de Janeiro: Fundação Casa de Rui Barbosa,1926c.

ANDRADE, Mário de. S. Paulo-20-II-27. Carta de Mário de Andrade a Carlos Drummond de Andrade, 20/02/1927. Rio de Janeiro: Fundação Casa de Rui Barbosa, 1927.

ANDRADE, Mário de. S. Paulo, 7-IV-28. Carta de Mário de Andrade a Manuel Bandeira, 07/04/1928. Rio de Janeiro: Fundação Casa de Rui Barbosa, 1928.

ANDRADE, Mário de. O Aleijadinho e Alvares de Azevedo. Rio de Janeiro: R. A., 1935.

ANDRADE, Mário de. Aspectos da literatura brasileira. Rio de Janeiro: Americ Edit, 1943.

ANDRADE, Mário de. As danças dramáticas no Brasil. In: LANGE, Curt; NICORA, Eduard (orgs.). Boletín Latino-Americano de Música, Primera Parte, Año VI, Tomo VI. Rio de Janeiro: Imprensa Nacional, 1946, pp. 49-97.

ANDRADE, Mário de. Contos novos. São Paulo: Martins, 1947.

ANDRADE, Mário de. A Augusto Meyer. São Paulo, 20-V-28. In: ANDRADE, Mário de. Mário de Andrade escreve cartas a Alceu, Meyer e outros. Rio de Janeiro: Editora do Autor, 1968, pp. 49-57.

ANDRADE, Mário de. Paulicea 30-V-923. Carta de Mário de Andrade a Sergio Milliet. In: DUARTE, Paulo. Mário de Andrade por ele mesmo. São Paulo: Edart-SP, 1971.

ANDRADE, Mário de. Aspectos da literatura brasileira. 4. ed. São Paulo: INL, Martins, 1972.

ANDRADE, Mário de. Poesias completas. Edição crítica e notas Diléia Zanotto Manfio. Belo Horizonte: Itatiaia, 1987.

ANDRADE, Mário de; BANDEIRA, Manuel. Correspondência. Mário de Andrade E Manuel Bandeira. Org., introdução e notas Marcos Antonio de Moraes. São Paulo: Instituto de Estudos Brasileiros/Universidade de São Paulo, 200o[1925].

ANÔNIMO. [Sem título]. O Rio Nú, Rio de Janeiro, 26 de outubro de 1898, p. 1. Disponível em: <http://memoria.bn.br/hdb/periodico.aspx>.

ANÔNIMO. Conversa fiada. O Rio Nú, Rio de Janeiro, 19 de abril de 1899, p. 2. Disponível em: <http://memoria.bn.br/hdb/periodico.aspx>.

ANÔNIMO. Concurso de resposta. O Rio Nú, Rio de Janeiro, 22 de agosto de 1900a, p. 3. Disponível em: <http://memoria.bn.br/hdb/periodico.aspx>. 
ANÔNIMO. Concurso de resposta. O Rio Nú, Rio de Janeiro, 15 de setembro de 19oob, p. 6. Disponível em: <http://memoria.bn.br/hdb/periodico.aspx>.

ANÔNIMO. Annuncios especiaes. O Rio Nú, Rio de Janeiro, 26 de março de 1904, p. 2. Disponível em: <http://memoria.bn.br/hdb/periodico.aspx>.

ANÔNIMO. Cartas sem... sê-lo. O Rio Nú, Rio de Janeiro, 27 de maio de 1905, p. 2. Disponível em: <http://memoria.bn.br/hdb/periodico.aspx>.

ANÔNIMO. Reclamam ao Rio Nú! O Rio Nú, Rio de Janeiro, 20 de abril de 1912, p. 3. Disponível em: <http://memoria.bn.br/hdb/periodico.aspx>.

BAHIANO. O Francesco. [S.1.]: Odeon, 1907-1912. Acervo de Música do Instituto Moreira Salles (IMS), Rio de Janeiro.

BOURDIEU, Pierre. A dominação masculina. Trad. Maria Helena Kühlner. 1o. ed. Rio de Janeiro: Bertrand, 2011.

BRAGA, Theophilo. [Estudo e notas sobre a vida]. In: FALCÃO, Christovam. Obras de Christovam Falcão: trovas de Chrisfal. Carta, cantigas e esparsas. Com estudo sobre sua vida, poesias e epoca por Theophilo Braga. Porto: Renascença Portuguesa, 1915.

BUTLER, Judith. El género en disputa: El feminismo y la subversión de la identidad. Trad. M. Antonia Muñoz. Barcelona: Paidós, 2007.

CASTRO, Moacir Werneck de. Mário de Andrade: exílio no Rio. Rio de Janeiro: Rocco, 1989.

COELHO, Nelly Novaes. Mário de Andrade para a jovem geração. São Paulo: Saraiva, 1970.

DUARTE, Paulo. Memórias 2: a inteligência da fome. 2. ed. São Paulo: Hucitec, 1975.

FIGARI, Carlos. @s “Outr@s” Cariocas: interpolações, experiências e identidades homoeróticas no Rio de Janeiro. Séculos XVIII ao XX. Rio de Janeiro: IUPERJ, 2007.

FOSTER, David William. Some Formal Types in the Poetry of Mário de Andrade. Luso-Brazilian Review, v. 2, n. 2, Winter 1965, pp. 75-95.

GINZBURG, Jaime. Fisionomia do narrador de um conto de Mário de Andrade. Letras 7 , Santa Maria, edição especial, 1993, pp. 104-109.

GOETHE, Johann Wolfgang von. The King of Thule. In: Faust: a tragedy. Boston: Ticknor and Fields, 1856 , pp. 134-135.

LAFETÁ, João Luiz. Figuração da intimidade: imagens na poesia de Mário de Andrade. São Paulo: Martins Fontes, 1986.

LOPEZ, Telê Ancona. Dona Olivia multiplicada. Verbo de Minas, Juiz de Fora, v. 11, n. 19, jan./jul. 2011, pp. 13-35. 
LOZANO, Jorge; PEÑA-MARÍN, Cristina; ABRIL, Gonzalo. Análise do discurso: por uma semiótica da interação textual. São Paulo: Littera Mundi, 2002.

MARAÑÓN, Gregorio. A evolução da sexualidade e os estados intersexuaes. Trad. Fioravanti di Piero. Rio de Janeiro: Minerva, 1938.

MARQUES, Raniere de Araújo. Modernização estética e sujeitos periféricos em Pauliceia Desvairada de Mário e Andrade. Tese (Mestrado Em Letras) - Universidade Federal da Paraíba, Centro de Ciências Humanas, Letras e ArtesJoão Pessoa, 2014.

MATTOS, Gregório de. Gregório de Mattos. In: BUENO, Alexei. Antologia pornográfica. Rio de Janeiro: Nova Fronteira, 2004.

MICELI, Sérgio. Intelectuais à brasileira. São Paulo: Companhia das Letras, 2001.

MICELI, Sérgio. Feição e circunstância de Mário de Andrade. Revista IEB, n. 47, set. 20o8, pp. 218-224.

MORAES, Eliane Robert. Erotismo em Mário de Andrade. In: FLIP 2015 - As margens de Mário. [Youtube]. Postado por FLIP - Festa Literária de Paraty, publicado em 27/8/2015. Disponível em: <https://www.youtube.com/watch?v=HNq2lgJZZ7Q>. Acesso em: 19 fev. 2016.

MORAES, Marcos Antonio de. [Introdução e notas]. In: ANDRADE, Mário de; BANDEIRA, Manuel. Correspondência. Mário de Andrade E Manuel Bandeira. Marcos Antonio de Moraes (org.). São Paulo: Instituto de Estudos Brasileiros/Universidade de São Paulo, 2000.

PÉREZ VILLALÓN, Fernando. Modernidad sincopada: música, ritmo y nación en la obra de Mário de Andrade. Revista Chilena de Literatura, Sept. 2015, n. 90, pp. 223-244.

PIERONI, Geraldo. Os excluídos do reino: a inquisição portuguesa e o degredo para o Brasil colônia. 2. ed. Brasília: Universidade de Brasília, 2006.

PRECIADO, Beatriz. Las subjetividades como ficciones políticas. [Youtube]. 14/2/2014. Postado por Kbeza Rodante. Disponível em:<https://www.youtube.com/ watch?v=R4GnRZ7_-w4>. Acesso em: 28 fev. 2016.

PRECIADO, Beatriz. Manifiesto contrasexual. Trad. Julio Díaz y Carolina Meloni. Barcelona: Anagrama, 2011.

QUEIROZ, Rachel de. Tantos anos: uma biografia. São Paulo: Siciliano, 1998.

RABELLO, Ivone Daré. A caminho do encontro: uma leitura de Contos novos. São Paulo: Ateliê, 1999 .

RAGO, Margareth. Amores lícitos e ilícitos na modernidade paulistana ou No Bordel de Madame Pomméry. Teoria E Pesquisa 47, jul./dez. 2005, pp. 93-118. 
RAGO, Margareth. Os prazeres da noite: prostituição e códigos da sexualidade feminina em São Paulo (189o-1930). Rio de Janeiro: Paz e Terra, 1991.

RIBEIRO, Leonídio. Homossexualismo e endocrinologia. Rio de Janeiro: Francisco Alves, 1938.

RIBEIRO, Leonídio. O novo código penal e a medicina legal. Rio de Janeiro: Jacintho, 1942.

ROUSSEAU, George Sebastian. Os infortúnios de Priapo: anticlericalismo, desejo homossocial e Richard Payne Knight. In: ROUSSEAU, G.S.; PORTER, Roy (orgs.). Submundos do sexo no iluminismo. Trad. Talita M. Rodrigues. Rio de Janeiro: Rocco, 1999 .

SALIH, Sara. Judith Butler e a teoria queer. Trad. Guacira Lopes Louro. Belo Horizonte: Autêntica, 2012.

SANTIAGO, Silviano. O cosmopolitismo do pobre: crítica literária e crítica cultural. Belo Horizonte: Editora UFMG, 2008.

SEDGWICK, Eve Kosofsky. Epistemología del armario. Trad: Teresa Bladé Costa. Barcelona: Ediciones de la Tempestad, 1998.

SILVA, José Fabio Barbosa da. Aspectos sociológicos do homossexualismo em São Paulo. Sociologia, São Paulo, Escola de Sociologia Política de São Paulo, V. XXI, n. 4, out. 1959, pp. 350-36o.

TRAVASSOS, Elizabeth. Os mandarins milagrosos: arte e etnografia em Mário de Andrade e Béla Bartók. Rio de Janeiro: Zahar, 1997.

TREVISAN, João Silvério. Devassos no paraíso: A homossexualidade no Brasil, da colônia à atualidade. 5. ed. Rio de Janeiro: Record, 2002[1986].

VAINFAS, Ronaldo. O trópico dos pecados: moral, sexualidade e inquisição no Brasil. Rio de Janeiro: Civilização Brasileira, 2010.

VEIGA, Vinicio da. O homem-homem no homem-mulher. Hoje, Periódico de Acçào Social, Rio de Janeiro, 19 maio 1921, p. 10.

VEIGA, Vinicio da. O homem sem máscara: pathologia social. Rio de Janeiro: Brasil Editora, 1921.

VERGARA, Jorge. Toda canção de liberdade vem do cárcere: homofobia, misoginia e racismo na recepção da obra de Mário de Andrade. 2018. Tese (Doutorado em Música) - Programa de Pós-Graduação em Música, Centro de Letras e Artes, Universidade Federal do Estado do Rio de Janeiro.

WHITAKER, Edmur de Aguiar. Contribuição ao estudo dos homossexuais. Archivos da Sociedade de Medicina Legal e Criminologia de São Paulo. Annaes da Primeira 
Semana Paulista de Medicina Legal, São Paulo: Imprensa Oficial do Estado, 1938, pp. 217-222. (Suplemento do Volume VIII de 1937).

WHITAKER, Edmur de Aguiar. Estudo biográfico dos homossexuais (pederastas passivos) da capital de São Paulo. Separata dos Arquivos da Polícia e Identificação, v. II, n. 1, 1938-1939. São Paulo: Tip. do Gabinete de Investigações, pp. 244-262. 